\title{
ArcheoSciences
}

Revue d'archéométrie

33 (suppl.) | 2009

Mémoire du sol, espace des hommes

\section{Geophysical Survey at archaeological site Kaszaper, Békés County, Hungary}

Peter Milo, László Lichtenstein, Zoltán Rózsa, Tomas Tencer, Zoltán

Fekete and Marek Vlach

\section{(2) OpenEdition}

12 Journals

\section{Electronic version}

URL: https://journals.openedition.org/archeosciences/1393

DOI: 10.4000/archeosciences. 1393

ISBN: 978-2-7535-1599-4

ISSN: $2104-3728$

Publisher

Presses universitaires de Rennes

\section{Printed version}

Date of publication: 30 October 2009

Number of pages: 115-116

ISBN: 978-2-7535-0943-6

ISSN: $1960-1360$

\section{Electronic reference}

Peter Milo, László Lichtenstein, Zoltán Rózsa, Tomas Tencer, Zoltán Fekete and Marek Vlach,

"Geophysical Survey at archaeological site Kaszaper, Békés County, Hungary", ArcheoSciences [Online], 33 (suppl.) | 2009, Online since 30 October 2011, connection on 01 February 2022. URL: http:// journals.openedition.org/archeosciences/1393 ; DOI: https://doi.org/10.4000/archeosciences.1393 


\title{
Geophysical Survey at archaeological site Kaszaper, Békés County, Hungary
}

\author{
Peter Miro*, László Lichtenstein **, Zoltán RózsA***, Tomáš Tencer****, \\ Zoltán Fekete***** and Marek V $\mathrm{LACH}^{* * * * * *}$
}

Key words: Magnetic prospection, Late Bronze Age stronghold, Medieval settlement, Hungary.

During the spring 2008 geophysical field survey was performed in south-eastern Hungary. The geophysical survey was carried out at the Bronze Age strongholds and nearby areas in the territory of Békés county. The aim of this article is to present the results from archaeological site Kaszaper. The archaeological site Kaszaper is situated on the north bank of Száraz-ér river, ca. $20 \mathrm{~km}$ to south-east of Orosháza. Main goal of the prospection was investigation of some interesting areas, chosen following the crop marks on satellites images. Coverage of prospected area in Kaszaper was ca. 4,2 ha. The Navmag SM-5 - Cesium Magnetometer from Scintrex Company (Canada) was used for collection of data. The measurement resolution for the geophysical prospection was 1.0 $\mathrm{m}$ in the $\mathrm{X}$ axis and ca. $0.15 \mathrm{~m}$ in the $\mathrm{Y}$ axis. As a basic framework for preliminary measurement processing was used special ZPRAC 32 software, for analyzing and visualization of acquired maps of magnetic measurements was used Surfer 8 software. GIS software ArcGIS Desktop 9.2 by ESRI was used for the presentation of complete maps and other analyses. Due to insufficient geodetic information for spatial orientation we used method combining GPS and total station measurements. These efforts had resulted in spatially corrected geographical and geophysical data which could give a good ground for further planning of future archaeological activities.

The archaeological site Kaszaper lies on the north bank of Száraz-ér river - ca. $4 \mathrm{~km}$ south-east of the Kaszaper village, ca. $2 \mathrm{~km}$ west of Mezőkovácsháza and ca. $2.5 \mathrm{~km}$ to north of Végegyháza. The survey and archaeological excavation confirmed, that extend of site is more than 30 hectares. The site was settled during the Bronze Age and Medieval Age. Dominant object is the stronghold dated in the Gáva culture (late Bronze Age). The stronghold covers an area about 240 by $280 \mathrm{~m}$. The survey detects also large settlement activities from the medieval period. In the west part of stronghold there are traces of medieval church with cemetery, excavated in years 1938 and 2003.

The geophysical survey was carried out in 5 sectors (three bigger and two smaller areas). In the whole prospected area were registered a number of magnetic anomalies, some them can be interpreted as archaeological structures. There were detected several archaeological objects - ditch system from the Bronze Age and medieval Period, palisades, traces of settlements, pits, houses and maybe graves. Some small dipole-anomalies with contrast high and lower magnetic values are small metal features (mostly recent). Most of the

\footnotetext{
* Peter Milo, Department of Archaeology and Museology, Masaryk University Brno, Arna Nováka 1, 60200 Brno, Czech Republic. (milop@post.sk)

** László Lichtenstein, Szántó Kovács János Regional Museum of Orosháza, Dózsa György utca 5, 5900 Orosháza, Hungary. (brvonlichtenstein@gmail.com)

*** Zoltán Rózsa, Szántó Kovács János Regional Museum of Orosháza, Dózsa György utca 5, 5900 Orosháza, Hungary. (rozo30@hotmail.com)

****Tomáš Tencer, Department of Archaeology and Museology, Masaryk University Brno, Arna Nováka 1, 60200 Brno, Czech Republic. (TomasTencer@seznam.cz)

**** Zoltán Fekete, Szántó Kovács János Regional Museum of Orosháza, Dózsa György utca 5, 5900 Orosháza, Hungary. (zfekete@gmx.net)

****** Marek Vlach, Department of Archaeology and Museology, Masaryk University Brno, Arna Nováka 1, 60200 Brno, Czech Republic. (75464@mail.muni.cz)
} 
magnetic anomalies can be interpreted as trace of intensive agricultural activities in the form of plough marks and fields boundaries (Fig. 1).

Good visible is ditch-system of Bronze Age stronghold (Fig. 2, 3:a). Fill of these structures differs in magnetic value from the surrounding soil. In field, partly visible, destruction of fortification (like a rampart) is encircling by three ditches. Width of ditches is approximately 2 to $4 \mathrm{~m}$. They lay ca. $1 \mathrm{~m}, 14 \mathrm{~m}$ and $40 \mathrm{~m}$ from predicted front-wall of rampart (fortification). Very interesting found is the structure, which can be interpreted like a front-wall of the fortification (Fig. 3:b). It can be seen in the magnetic map as a long linear features with high and low magnetic values. In the middle of this long and thin (not more than $1 \mathrm{~m}$ ) structure are good visible white points, they can be interpreted like big wooden posts. Relatively high magnetic values suggest that construction was destroyed by fire. We assume, this is rest of front-wall palisade of a rampart. In some parts of magnetic map, close behind the palisade there are good visible two stripes with higher positive magnetic values (Fig. 3:c). We suppose that they belong to wood construction of rampart. At inner side of fortification was probably some kind of ramp (Fig. 3:d). The fortification of stronghold was in year 2007 excavated also archaeologically (Excavations of Szántó Kovács János Regional Museum of Orosháza provided by L. Lichtenstein and Z. Rózsa). Three of seven excavated trenches lies in geophysical prospected area. The results of archaeological excavation can be good compare with the results of magnetic measurement (Fig. 3).

Other archaeological structures are visible outside of stronghold (Fig. 1, 2). Some long linear structures can be interpreted as ditches. They are not so demonstrative like those from the stronghold. Obviously these ditches are less deeper and less wider. Interpretation of these structures is

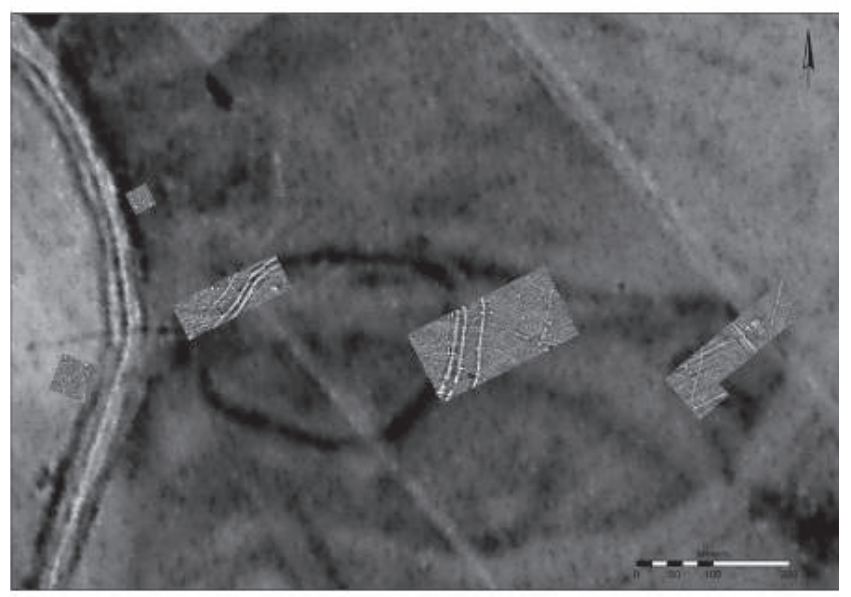

Figure 1: Kaszaper. Magnetometer-survey. not clear. They can be interpreted as border of medieval households. Linear features with SW-NE direction must be interpreted like traces of intensive agricultural activity. One $10 \times 17 \mathrm{~m}$ large anomaly looks like ground plan of longhouse. This house is probably from the medieval period. Some positive mono-anomalies can be interpreted like pits, oven or sunken huts. In the whole prospected area are about 25 anomalies of this kind. One detected anomaly can be interpreted like a grave with circular ditch around. Two circular structures with diameter about $10 \mathrm{~m}$ can be interpreted as a big pits or maybe barrows.

Larger geophysical prospection (planned for spring 2009) together with archaeological verification of some detected structure can say more information about the site.

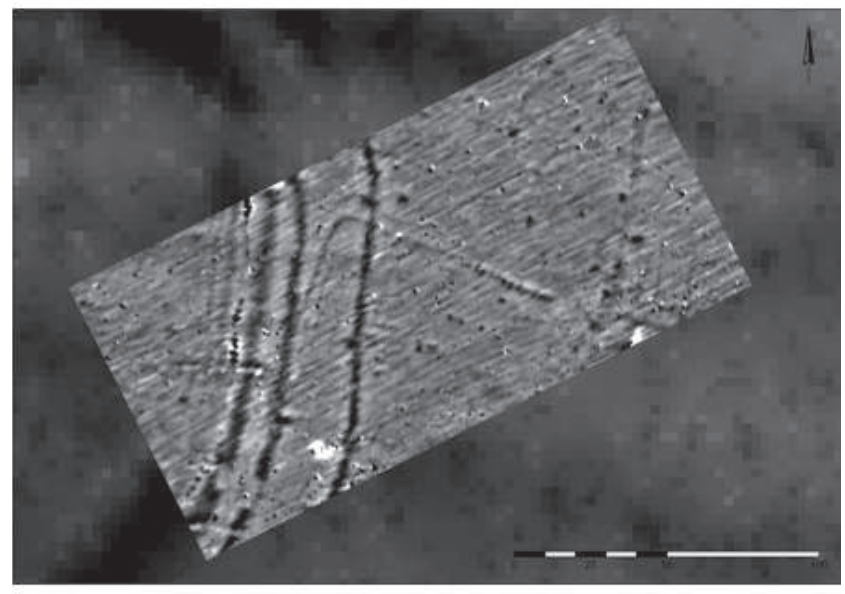

Figure 2: Kaszaper. Section from a central part of magnetic map. Dynamics: $-3 /+3 \mathrm{nT} / \mathrm{m}$ in 256 grayscales (white/black, linear), raster $0,15 \mathrm{~m} / 1 \mathrm{~m}$.

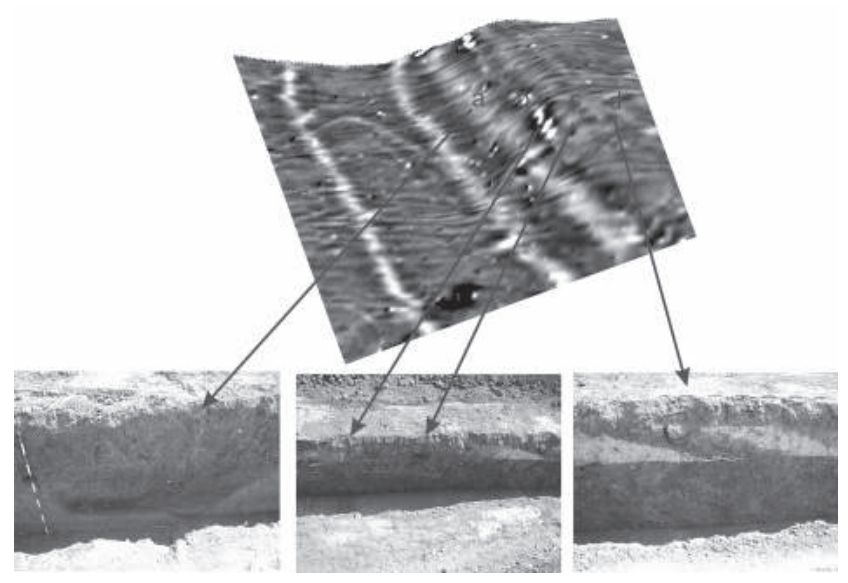

Figure 3. Kaszaper. Comparison of result from magnetic prospection with situation in archaeological excavated trenches. a. Ditch, b. Palisade, c. Possible construction inside of rampart, d. Ramp. 